\title{
DESIGNING WORK FOR MENTAL HEALTH: THE MODERATING ROLE OF JOB RESOURCES
}

Karmen DEŽMAR KRAINZ

Croatian Institute for Health Protection and Safety at Work, Zagreb

Josip MIKULIĆ

Faculty of Economics and Business, Zagreb

Helena KOREN

Croatian Institute for Health Protection and Safety at Work, Zagreb

Ana ZAVALIĆ

Zagreb County Health Center, Zaprešić

UDK: 005.32:159.913

Izvorni znanstveni rad

Primlieno: 1. 12. 2017.

The aim of this article is to investigate the relationship between work design characteristics and employee health outcome. Specifically, job resources (i.e. managerial support, co-worker support and information about organizational changes) were examined as moderators of the relationship between job demands (i.e. workload and lack of control) and mental health. Following the job demands-resources model, and by using partial-least squares structural equations modelling, this study provides empirical evidence that job demands are negatively related to employees' mental health on a sample of 383 public transportation drivers. Furthermore, as the results reveal, job resources relieve the negative impact of job demands thus providing an alternative for avoiding the health impairment process.

Keywords: work design, job demands-resources model, mental health, Croatia

$\bowtie \quad$ Karmen Dežmar Krainz, Croatian Institute for Health Protection and Safety at Work, Radoslava Cimermana 64, 10020 Zagreb, Croatia. E-mail: kdezmar@gmail.com 
Nowadays employees work more intensely experiencing greater mental strain, sometimes to the point of exhaustion. One of the key features of contemporary work is that it is becoming increasingly demanding (Green, 2006). As a consequence of demanding work, mental health problems, which have become the leading cause of sick leaves in the majority of European countries, arise. Moreover, given this trend, mental health problems may even turn into the leading cause of occupational diseases and absenteeism (Wynne \& MacAnaney, 2004).

New working requirements have initiated huge changes in work design (i.e. a system of schedules and procedures for the organisation of work; Sinha \& Van de Ven, 2005), and they have also moved the focus to different work design characteristics, new outcomes of work and underlying psychological mechanisms that connect them (Panatik, 2010). Proper work design aims at ensuring high levels of job demands while, at the same time, mitigating their negative effects. Work design researchers are thus constantly trying to comprehend work design characteristics which enhance work satisfaction and motivate workers to achieve organisational goals (Sikavica \& Hernaus, 2011).

The increased complexity of many jobs and heightened concerns about health issues in society highlight the need for more attention to designing healthy work (Parker, 2014). Poorly designed work potentially causes great damage to individuals in the sense of dissatisfaction, demotivation and imbalance between private and business life, which may be the cause of stress, subsequently contributing to the development of numerous mental and physical illnesses.

The relationship between work design and employee health has been subject to many studies during the past decades (e.g., Karasek, 1979; Warr, 1994). Over the past 30 years, several conceptual models, such as the job characteristics model (Hackman \& Oldham, 1976), the job demand-control model (Karasek, 1979), and the vitamin model (Warr, 1994), among others, have been developed to explain the impact of work design on employee health and well-being (Panatik, 2010).

Although organisational behaviour researchers have extensively studied the relationships between work design characteristics and various individual outcomes for many years, it is still unknown whether job resources have the potential to mitigate negative effects of the psychosocial work environment, consequently ensuring better mental health for employees. The present study aims to address this research gap by applying the job demands-resources model (JD-R model) as a comprehensive framework which is applicable to different occupations, irrespective of specific work demands and resources 
DRUŠ. ISTRAŽ. ZAGREB GOD. 28 (2019), BR. 1 STR. 47-67

DEŽMAR KRAINZ, K. ET AL.: DESIGNING...
(Demerouti, Bakker, Nachreiner, \& Schaufeli, 2001). More specifically, this paper focuses on several job resources (i.e. managerial support, co-worker support and information about changes) as potential moderators of the relationship between job demands (i.e. workload and lack of control) and mental health.

In order to analyse the hypothesised relationships and influences, this study uses a sample of public transportation drivers (PTDs) from Croatia. It is rather commonly known that tasks related to this occupation are highly mentally demanding because PTDs have to cope with conflicting requirements (Kompier \& Di Martino, 1995; Useche, Alonso, Cendales, Autukevičiūtè, \& Serge 2017). In this regard, the buffering role of job resources may be very important in mitigating the negative effects of PTD work. So far, research has focused on the moderating effects of job resources on different individual outcomes, involving e.g. burnout (e.g. Xanthopoulou et al., 2007), workload, time pressure, and job strain (Johnson \& Hall, 1988), emotional exhaustion (De Jonge \& Dormann, 2006), or work engagement (Bakker, Hakanen, Demerouti, \& Xanthopoulou, 2007). To the knowledge of the authors of this article, no study has, however, so far focused on mental health as an individual outcome.

Accordingly, the main contribution of this article is manifested in applying the JD-R model as a theoretical framework for analysing the moderating role of job resources on mental health. So far, several work design studies have been conducted with a focus on Croatian employees (e.g. Hernaus, 2010; Hernaus \& Mikulić, 2014; Hernaus \& Pološki Vokić, 2014), but none of them has centred on the JD-R model.

\section{MENTAL HEALTH AT THE WORKPLACE}

Work plays an important role in the mental health and well-being of an individual. It is a source of identity, sense of self-esteem and purpose, but it also provides financial resources, poses time structures and requires social contact. Likewise, however, low quality of work can negatively influence a person's mental health. More specifically, poor working conditions and inadequate work design at the workplace can deteriorate mental health, which can be defined as "a state of well-being in which an individual realises his or her own abilities, can cope with the normal stresses of life, can work productively and is able to make a contribution to the community" (WHO, 2004).

Mental illness often considers mental disorders that are conditions clinically significant, characterised by altered thoughts, emotions or behaviours with associated distress and impaired functioning (WHO, 2005). Depression and mood disorders, 
DRUŠ. ISTRAŽ. ZAGREB GOD. 28 (2019), BR. 1, STR. 47-67

DEŽMAR KRAINZ, K. ET AL.: DESIGNING... anxiety and substance abuse are the most prevalent mental health problems. Depression is one of the most common mental disorders appearing among both the general population and at the workplace (WHO, 2005). Anxiety is, in fact, a normal human experience. However, when it persists and overwhelms a person, it can lead to inefficient functioning by affecting cognitive functions which are needed to complete tasks. Finally, abuse of substances, such as e.g. alcohol, marihuana and other drugs, is a significant problem that leads to behavioural and safety problems, increased rates of errors and accidents at work, aggressive behaviour and workplace violence. Mental health problems are much more complex than the aforementioned disorders. Many individuals may experience symptoms of distress that do not meet the criteria for diagnosis of a mental disorder, but still, they significantly affect an individual's quality of life and ability to function properly. As such, they are referred to as sub-clinical disorders with a high prevalence among the working population. They include, e.g. fatigue and sleep difficulties, low mood, irritability or excessive worry. Current estimates suggest that about $25 \%$ of European citizens will experience some mental health problem in their lifetime, and approximately $10 \%$ of longterm health problems and disabilities can be linked to mental and emotional disorders (ENWHP, 2009). According to data of the Croatian Institute for Public Health, mental health problems in Croatia account for about 4 to $5 \%$ in primary health care, with neurotic, stress-related and somatoform disorders as most commonly registered diagnoses (Silobrčić Radić \& Jelavić, 2011). The share of hospitalisations due to mental health problems ranges from 6 to $7 \%$. Most patients are aged between 20 and 59, thus suggesting that mental health disorders are one of the leading causes of hospitalisations among the working population in Croatia.

The workplace is certainly an important social context which can play a significant role in the development of mental health problems. There is consistent evidence that high job demands, low job control and effort-reward imbalance are risk factors for mental and physical health (WHO, 2010). According to a meta-analysis conducted by Stansfeld and Candy (2006), high work demands paired with low decision latitude, as well as high efforts and low rewards represent risk factors for common mental disorders. Moreover, their analysis shows that low decision authority, low decision latitude, high job demands, low occupational social support and job insecurity are associated with a moderate risk of common mental disorders. Conversely, two dimensions of job design, i.e. social support and decision latitude, have been consistently identified as key protective factors for mental health. 


\section{IMPORTANCE OF WORK DESIGN FOR MENTAL HEALTH}

In recent years, increasing researchers' attention has been paid to work design as a determinant of positive employees' outcomes and subsequently, effective functioning of organisations and the society as a whole. Throughout history, work design researchers were trying to figure out which work characteristics make people happy with their work and motivate them to achieve organisational goals (Van den Broeck, Holman, \& Parker, 2017).

Well-designed work can result in many positive outcomes such as job satisfaction, work engagement, better physical and mental health, higher levels of innovation, while poorly-designed work results in negative outcomes such as increased number of accidents at work, occupational diseases, job dissatisfaction, absenteeism, turnover, lower well-being, etc. It is therefore not surprising that researchers have aimed to examine which work characteristics contribute to well-being and engagement of employees, on the one hand, and which ones to job stress and work-related diseases, on the other hand (Tims, Bakker, \& Derks, 2013).

The relationship between work design and employee health has been of particular interest for many decades. In order to conceptualise relevant relationships, several theoretical models have been developed which describe the impact of work design on health and well-being of employees (Panatik, 2010). The model that has initiated occupational health research in the job design domain is the demands-control model of strain by Karasek (1979). The model was later extended by Karasek and Theorell (1990) to include social support (i.e. the demand-control-support model), which proposes that high job demands (e.g. high workload), low social support and low decision latitude (i.e. low job control and skill discretion) will lead to strain on employees, as well as stress-related physical symptoms, such as, e.g. heart conditions (Parker \& Zhang, 2016).

More recently, with the introduction of the job demands-resources (JD-R) by Demerouti et al. (2001), the scope of job design research has been broadened. According to the JD-R model, a clear distinction is made between job demands, on the one hand, and job resources, on the other (Tims et al., 2013). The model is comprehensive in a way that it may be applied to various occupational settings, irrespective of particular demands and/or resources involved.

Job demands refer to "those physical, psychological, social or organisational aspects of the job that require sustained physical or mental effort and are therefore associated with certain physiological and psychological costs" (Demerouti et al., 2001). Examples include high work pressure, an unfavour- 
DRUŠ. ISTRAŽ. ZAGREB GOD. 28 (2019), BR. 1, STR. $47-67$

DEŽMAR KRAINZ, K. ET AL.: DESIGNING... able physical environment, irregular working hours, or emotionally demanding interactions with clients (Demerouti \& Bakker, 2011). On the other hand, job resources are "physical, psychological, social, or organisational aspects of the job that may do any of the following: be functional in achieving work goals, reduce job demands at the associated physiological and psychological costs, stimulate personal growth and development" (Demerouti et al., 2001). In brief, job demands include elements that require physical or psychological effort, while job resources help an employee deal more easily with job demands (Oldham \& Fried, 2016).

The interaction between job demands and job resources can lead to dual psychological processes. The first process is health impairment, which suggests that demanding jobs or jobs with chronically high job demands exhaust employees' mental and physical resources and may therefore lead to depletion of energy and to health problems (Bakker, Demerouti, \& Schaufeli, 2003). The second one is a motivational process, whereby it is assumed that job resources lead to higher work engagement, lower levels of cynicism and excellent performance (Bakker \& Demerouti, 2007).

In general, the consequences of work design encompass behavioural outcomes (e.g. work performance or absenteeism), psychological outcomes (e.g. job satisfaction or stress) as well as physical outcomes (e.g. high blood pressure and cardiovascular diseases) (Grant \& Parker, 2009). It is further known that job demands may turn into stressors especially in cases when a lot of effort is required to maintain expected levels of performance, consequently leading to negative conditions, such as burnout and depression (Schaufeli \& Bakker, 2004).

To summarise, the JD-R model states that job demands initiate a health-impairment process, while job resources initiate a motivational process (Tims et al., 2013). More specifically, high levels of job demands may exhaust employees' physical and mental resources, thus causing a decrease in energy and leading to health problems. However, there is a general lack of research which examines the effects of job demands specifically on the mental health of employees. Accordingly, the present study seeks out to empirically explore the relationship between two job demands variables, i.e. workload and lack of control, on the one hand, and employee mental health, on the other. Thereby, this relationship is expected to be negative:

H1: Job demands are negatively related to mental health of employees.

Analogously, following the basic assumptions of the JD-R model, high levels of job resources are expected to act moti- 
DRUŠ. ISTRAŽ. ZAGREB GOD. 28 (2019), BR. 1 STR. 47-67

DEŽMAR KRAINZ, K ET AL.: DESIGNING..

$\rightarrow$ FIGURE

Research model with hypothesised relationships vationally and thus they may lead to employees' engagement, goal-directed behaviour and well-being (Bakker \& Demerouti, 2007). In this regard, different job resources may buffer demanding working conditions and they could thus be expected to mitigate the negative impact of job demands on employee health. Accordingly, the present study seeks out to test the potential moderating effects of three job resources variables (i.e. managerial support, co-worker support and information about organisational changes) on the hypothesised negative relationship between job demands and employees' mental health:

$\mathrm{H} 2$ : Job resources positively moderate the relationship between job demands and mental health of employees.

A graphical representation of the research model is provided in Figure 1.

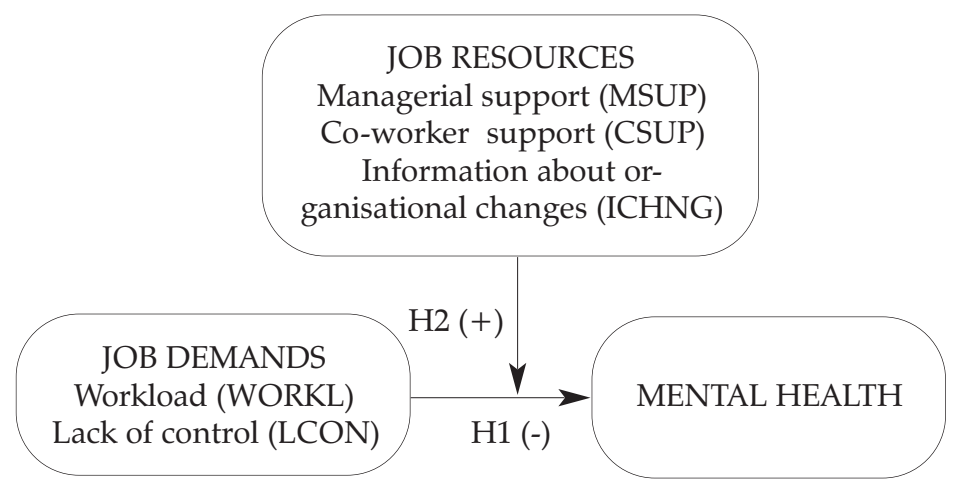

\section{RESEARCH METHOD}

\section{Sample and data collection}

The data used in this study were collected from 383 public transportation drivers (PTDs) employed at transportation service organisations in Croatia. Prior to collecting the data using structured pen-and-pencil questionnaires, all survey participants were informed and familiarised with the purpose of the study. Data collection took place during April and May 2016 after the participants had been approached by the management of their respective company. The survey questionnaire encompassed measures of job design and mental health as required for testing the main research hypotheses outlined above.

The questionnaires were delivered to the first line management which was responsible for questionnaire distribution among participants. The survey participants were then 
DRUŠ. ISTRAŽ. ZAGREB GOD. 28 (2019), BR. 1, STR. 47-67

DEŽMAR KRAINZ, K. ET AL.: DESIGNING..

\section{○ TABLE 1 \\ Sociodemographic and work-related respondent} characteristics approached at the five most frequent locations during the two peak hours of the day. Finally, they were asked to return the questionnaires into the marked boxes at their workplace in order to ensure confidentiality. The sample characteristics are presented in Table 1.

\begin{tabular}{llrr}
\hline Variable & & $N$ & $(\%)$ \\
\hline Gender & Male & 345 & 90.1 \\
& Female & 38 & 9.9 \\
Age & $20-34$ & 44 & 11.5 \\
& $35-44$ & 101 & 26.5 \\
& $45-54$ & 147 & 38.6 \\
& $55-64$ & 89 & 23.4 \\
Education level & High school up to 3 years & 166 & 44.0 \\
& High school up to 4 years & 193 & 51.2 \\
& University & 17 & 4.5 \\
Occupational group & Postgraduate studies & 1 & 0.3 \\
& Bus drivers & 260 & 67.9 \\
& Tram drivers & 118 & 30.8 \\
& Invalid vehicle drivers & 5 & 1.3 \\
& & $M$ & $S D$ \\
\hline Age & & 46.97 & 9.21 \\
Organisation tenure & & 17.27 & 9.45 \\
Years of shift work & & 16.46 & 9.24 \\
Working hours per week & & 41.71 & 3.14 \\
\hline
\end{tabular}

The measures used to operationalise focal job demands and job resources variables were obtained from the Health and Safety Executive Indicator Tool (HSE, 2004; Edwards, Webster, Van Laar, \& Simon, 2008). Due to the formative character of the job characteristics indicators, index scores were calculated rather than scale scores, since the former do not assume strong mutual correlation among all the respective indicators. Overall, this study focused on five work characteristics variables: (i) workload (eight items) measures high demands, time pressures and work patterns; (ii) control (six items) reflects the extent to which the employees can influence the way they do their work; (iii) managerial support (five items) represents encouragement, sponsorship and resources provided by the employer; (iv) co-worker support (four items) measures colleague encouragement and support at work; and (v) information about organisational changes (three items) measures how organizational change is managed and communicated at work. The survey participants indicated their responses on Likert scales ranging from 1 (never / strongly disagree) to 5 (always / strongly agree). 
DRUŠ. ISTRAŽ. ZAGREB GOD. 28 (2019), BR. 1 STR. 47-67

DEŽMAR KRAINZ, K ET AL.: DESIGNING..

\section{Data analysis}

The focal dependent variable in this study, i.e. mental health, was operationalised as a four-dimensional higher order construct based on scales from the SF-36 questionnaire (Ware, Snow, Kosinski, \& Gandek, 1993), i.e.: (i) vitality (four items) measures the level of energy and fatigue; (ii) role emotional (three items) relates to limitations due to emotional problems; (iii) social functioning (two items) reflects the quantity and quality of social activities; and (iv) mental health (five items) includes measures of anxiety, depression, loss of behavioural/ emotional control and psychological well-being (Ware et al., 1993). The final score of each of the above-mentioned dimensions was transformed to a scale from 0 (bad) to 100 (excellent). Cronbach alpha values for the mental health scales confirm high internal consistency, which indicates validity of the measurement instruments: vitality (0.87), role emotional (0.81), social functioning (0.74) and mental health (0.85). McHorney, Ware, Lu, and Sherbourne (1994) tested psychometric characteristics of the SF-36 questionnaire and reported high internal consistency coefficients for these scales that ranged from 0.83 for role emotional to 0.90 for mental health.

In order to test the previously outlined hypotheses, this study uses the structural equations modelling (SEM) technique. In its essence, SEM combines the advantages of multiple regression and factorial analyses, thus facilitating simultaneous fitting of a series of relationships between focal theoretical constructs, which are measured as latent variables using multiple, manifest indicators. In particular, this study employed variance-based, partial least squares SEM (PLS-SEM) using the SmartPLS modelling software (Ringle, Wende, \& Will, 2005).

Since the primary objective of the study was to test the potential moderating role of selected job resources with regard to the direct relationship between job demands and mental health, we took advantage of the product-term approach as described by Fassott, Henseler, and Coelho (2016) and Henseler and Fassott (2010). This approach encompasses two main steps, i.e. assessments of the main effects model and assessments of the moderated model. The main effects model tests the relationships between the focal independent variable (i.e. job demands), the moderating variable (i.e. job resources) and the dependent variable (i.e. mental health). The moderated model, in turn, further encompasses an interaction term variable which is created by multiplying the indicators of the independent and the moderating variables. In cases when the focal latent variables are formatively rather than reflectively identified, latent variable scores are initially calculated prior to creating the interaction term variable (Chin, Marcolin, \& Newsted, 2003). 
DRUŠ. ISTRAŽ. ZAGREB GOD. 28 (2019), BR. 1, STR. 47-67

DEŽMAR KRAINZ, K. ET AL.: DESIGNING..
Hereafter, the existence of potential moderating effects can be assessed as follows. If the path coefficient between the interaction variable and the dependent variable is statistically significant, while the direct effect of the moderator variable decreases as compared to the main effects model, then this can be regarded as empirical proof that the moderator variable indeed influences the focal relationship between the independent and the dependent variable. Moreover, the coefficients of determination $\left(R^{2}\right)$ of the main effects and moderated models can be compared in order to assess the strength of the moderating effect following Equation 1 (Henseler \& Fassott, 2010):

$$
f^{2}=\frac{R^{2} \text { model with moderator }-R^{2} \text { model without moderator }}{1-R_{\text {model with moderator }}^{2}}
$$

Based on Henseler and Fassott (2010), moderating effects with effect sizes $\left(f^{2}\right)$ of 0.02 can be described as weak, $f^{2}$ values above 0.15 indicate a moderate moderating effect, whereas $f^{2}$ values above 0.35 a strong moderating effect.

\section{RESULTS}

(1) TABLE 2

Means, standard deviations and correlations
Means, standard deviations and correlations among the research variables are shown in Table 2 . For the purpose of discriminant validity assessments, square roots of the average variances extracted (AVE) for the reflectively identified variables are depicted along the table's diagonal.

\begin{tabular}{|c|c|c|c|c|c|c|c|c|c|c|c|c|c|}
\hline & & $M$ & $S D$ & 1 & 2 & 3 & 4 & 5 & 6 & 7 & 8 & 9 & 10 \\
\hline 1 & Workload & 2.80 & 0.59 & n.a. & & & & & & & & & \\
\hline 2 & Lack of control & 3.44 & 0.69 & $0.154^{* *}$ & n.a. & & & & & & & & \\
\hline 3 & Manager support & 3.17 & 0.83 & $-0.435^{* *}$ & $*-0.386^{* *}$ & n.a. & & & & & & & \\
\hline 4 & Colleagues' support & 3.29 & 0.70 & $-0.151^{*}$ & $-0.364^{* *}$ & $0.542^{* *}$ & n.a. & & & & & & \\
\hline 5 & Information about or- & & & & & & & & & & & & \\
\hline & ganisational change & 2.98 & 0.72 & $-0.307^{* *}$ & $-0.393^{* *}$ & $0.668^{* *}$ & $0.417^{* *}$ & n.a. & & & & & \\
\hline 6 & Vitality & 62.23 & 17.98 & $-0.427^{* *}$ & $*-0.216^{* *}$ & $0.394^{* *}$ & $0.155^{*}$ & $0.361^{* *}$ & 0.874 & & & & \\
\hline 7 & Social functioning & 77.01 & 21.17 & $-0.376^{* *}$ & $* 0.066$ & $0.249^{* *}$ & 0.068 & $0.210^{* *}$ & $0.698^{* *}$ & 0.748 & & & \\
\hline 8 & Role emotional & 87.02 & 28.49 & $-0.266^{* *}$ & $* 0.073$ & $0.168^{* *}$ & 0.075 & $0.126^{*}$ & $0.457^{* *}$ & $0.475^{* *}$ & 0.874 & & \\
\hline 9 & Mental health & 71.98 & 15.66 & $-0.390^{* *}$ & $*-0.200^{* *}$ & $0.350^{* *}$ & $0.211^{* *}$ & $0.297^{* *}$ & $0.824^{* *}$ & $0.648^{* *}$ & $0.472^{* *}$ & 0.844 & \\
\hline 10 & Mental health latent & 74.78 & 17.12 & $-0.443^{* *}$ & $*-0.142^{* *}$ & $0.312^{* *}$ & $0.128^{*}$ & $0.274^{* *}$ & $0.859^{* *}$ & $0.838^{* *}$ & $0.789^{* *}$ & $0.841^{* *}$ & n.a. \\
\hline
\end{tabular}

\section{Measurement model and structural model assessments}

As outlined earlier, internal consistency assessments for the reflectively identified variables indicate sufficient levels of measurement reliability and validity. Moreover, all reflectively identified latent variables meet the Fornell-Larcker criterion of discriminant validity, meaning that the variables are sufficiently distinct from each other, which is considered a neces- 
DRUŠ. ISTRAŽ. ZAGREB GOD. 28 (2019), BR. 1 STR. 47-67

DEŽMAR KRAINZ, K. ET AL.: DESIGNING... sary precondition for structural model assessments (Fornell \& Larcker, 1981). As can be seen from Table 2, the square root of AVE scores for each reflectively measured variable exceeds respective coefficients of correlation of the focal variable with all other model variables. With regard to the formatively identified model variables, the relatively lower magnitudes of correlation between them can also be regarded as indication of discriminant validity.

Overall, this study focuses on two job demands components, i.e. (i) workload (WORKL) and (ii) lack of control (LCON), and three different job resources components, i.e. (i) managerial support (MSUP), (ii) co-worker support (CSUP), and (iii) information about organisational changes (ICHNG). Accordingly, six different structural models were created in order to assess potential moderating effects of each individual job resource component on one and the other job demands component. The bootstrapping procedure was used in order to obtain significance levels for calculated path coefficients.

Table 3 provides the results of conducted structural model assessments.

\section{The moderating role of managerial support}

The results for the main effects model reveal that both workload and lack of control, as important job demands components, have a statistically significant, negative impact on mental health. This said, it has further to be highlighted that the magnitude of the effect of workload $(\beta$ WORKL $=-0.480)$ is far larger than the effect of lack of control $\left(\beta_{L D C O N}=-0.175\right)$. With regard to the analysed moderating variable, i.e. managerial support, the results of the main effects model further confirm a significant and positive, direct impact on mental health $(\beta$ MSUP $=0.309)$.

With regard to its potential moderating role, Model 1 provides empirical confirmation for a significant moderating influence of managerial support on the relationship between workload and mental health $\left(\beta\right.$ WORKL ${ }^{*}$ MSUP $\left.=0.283\right)$. The results show that with increasing managerial support, the negative influence of workload on mental health significantly decreases.

Likewise, Model 2 confirms a significant moderating effect of managerial support on the relationship between lack of control and mental health $\left(\beta\right.$ LCON $^{*}$ MSUP $=0.187$; at the $5 \%$ significance level). Here, with increasing managerial support, the negative effect of lack of control on mental health also decreases with higher levels of managerial support. In contrast to the first moderated model, there remains, however, also a significant direct effect of managerial support on mental health. 
DRUŠ. ISTRAŽ. ZAGREB GOD. 28 (2019), BR. 1, STR. 47-67

DEŽMAR KRAINZ, K. ET AL.: DESIGNING..

2 TABLE 3

Managerial support, co-worker support and information about organisational change as moderators of the relationship between

job demands and mental health

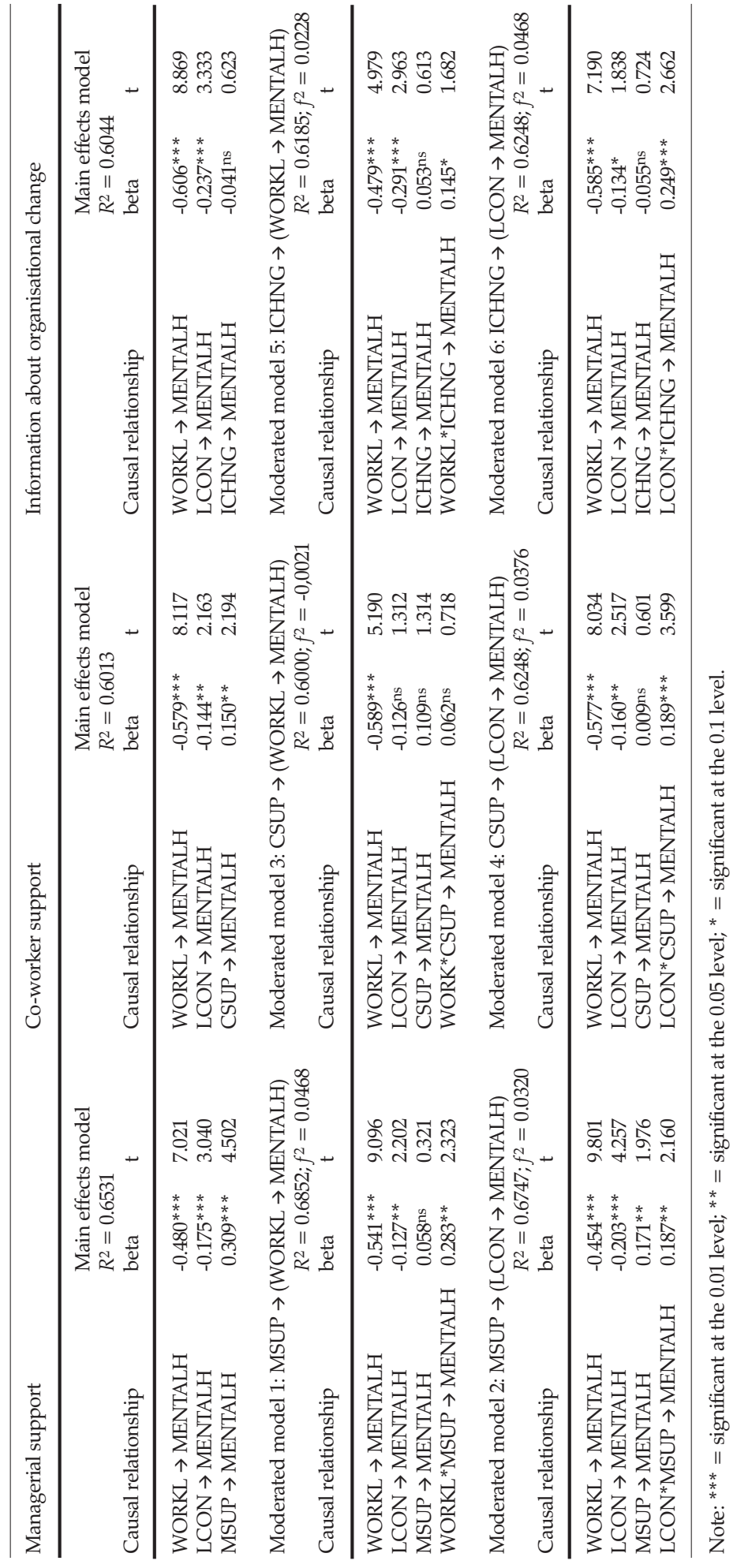


DRUŠ. ISTRAŽ. ZAGREB GOD. 28 (2019), BR. 1 STR. 47-67

DEŽMAR KRAINZ, K. ET AL.: DESIGNING...
The moderating role of co-worker support

With regard to co-worker support, as an important job resource component, results of the main effects model revealed a significant direct effect on mental health. As compared to managerial support, the effect of co-worker support on mental health is far smaller $(\beta$ csuP $=0.150$; at the $5 \%$ significance level).

With regard to the moderating influence of co-worker support, Model 3 reveals that this job resource variable does not significantly lower the negative effect of workload on mental health $\left(\beta\right.$ WORKL ${ }^{*} C S U P=0.062$; not significant), although the direct effect turns statistically insignificant. Model 4 reveals, however, that co-worker support does significantly moderate the relationship between job autonomy and mental health, i.e. that higher co-worker support enhances the effect of autonomy on mental health $\left(\beta\right.$ LCON $^{*}$ CSUP $=0.189$; significant at the $1 \%$ level).

The moderating role of information about organisational change With regard to information about organisational change, the results of the main effects model do confirm the significance of a direct effect on mental health (BICHNG $=-0.041$ ), unlike for the previously analysed job resources. Interestingly, however, both moderated models confirm the existence of a significant moderating influence on the relationships between the two job demands variables, on the one hand, and mental health, on the other hand.

Model 5 reveals that information about organisational change has a marginal but significant influence on the relationship between workload and mental health ( $\beta$ WORKL ${ }^{*}$ ICHNG $=0.145$; significant at the $10 \%$ level). The effect is in the expected direction, meaning that higher awareness buffers the negative influence of workload on mental health. Furthermore, Model 6 shows that this job resource has a far stronger moderating effect on the relationship between job autonomy and mental health $\left(\beta_{L C O N}{ }^{I C H N G}=0.249\right.$; significant at the $1 \%$ level).

Finally, as predicted, the obtained results confirm hypothesis $\mathrm{H} 1$ by showing that high job demands are negatively related to mental health. However, hypothesis $\mathrm{H} 2$ is only partially confirmed. Indeed, it has been confirmed that job resources mitigate the negative effect of job demands on mental health, except for the moderator variable of co-worker support on the relationship between workload and mental health.

\section{DISCUSSION}

The present study used the JD-R model as an overarching theory to examine how job demands and job resources are related to the mental health of PTDs. In analysing the results, the nature of PTDs should be taken into account, as this is an 
DRUŠ. ISTRAŽ. ZAGREB GOD. 28 (2019), BR. 1, STR. 47-67

DEŽMAR KRAINZ, K. ET AL.: DESIGNING... occupational group whose work is both mentally and physically very demanding (Useche et al., 2017).

The results of the conducted structural model assessments provide empirical support for hypothesis $\mathrm{H} 1$, thus confirming that workload and lack of control have a statistically significant negative impact on employees' mental health and thus may lead to the depletion of energy and to health problems (Demerouti et al., 2001). The latter development is a theoretical proposition of the JD-R model which poses that job demands instigate a health impairment process. In their original article, Demerouti et al. (2001) showed that job demands were the predictors of exhaustion, i.e. that they were primarily and positively related to exhaustion. Generally speaking, it is expected that in a work situation characterised by high job demands and limited job resources, employees develop exhaustion, cynicism and reduced sense of competence that leads to burnout (Bakker et al., 2003).

According to the results of our study, 7.7\% of PTDs stated to have subjective mental health problems, like depression or anxiety. Respondents self-estimated their general mental health as being good, although the results indicate lower levels of vitality, manifested through the feeling of exhaustion, lack of energy, worn out condition and tiredness.

According to the JD-R model, it can be expected that the existence of favourable job resources might buffer the negative impact of high job demands of PTDs on their mental health (H2). The results of respective structural model assessments partially confirm hypothesis $\mathrm{H} 2$, showing that employees who receive higher levels of job resources are less vulnerable to the negative effect of job demands on their mental health than employees with lower levels of job resources. Moreover, job resources, managerial support and co-worker support have a direct positive effect on mental health, while information about organisational change does not exhibit a significant impact. Social support - including managerial and co-worker support - is probably one of the most helpful resources that buffer the impact of stressors on strain and other indicators of well-being (Panatik, 2010).

Previous studies have shown that high-quality relationships with managers may alleviate the negative influence of job demands (e.g. workload, emotional and physical demands) on job strain (Bakker \& Demeroutti, 2007). Moreover, co-worker support may generate positive feelings that may enhance an individual's capacity to adapt to stressful situations (Panatik, 2010). Social support is important for numerous reasons as it provides instrumental and emotional support to employees and contributes to problem-solving, as well as protects them from the negative consequences of work-related stressors (Panatik, 2010). 
DRUŠ. ISTRAŽ. ZAGREB GOD. 28 (2019), BR. 1 STR. 47-67

DEŽMAR KRAINZ, K. ET AL.: DESIGNING...
Contrary to our expectations, information about organisational change did not emerge to have a significant direct effect on mental health, although it was positively related to mental health. Obviously, the surplus of information has potentials to positively influence mental health, but being better informed will not necessarily improve the employee's mental health, as this probably also depends on the nature of information.

Furthermore, this study tested the potential moderating effect of job resources on the negative relationship between job demands and mental health. The results confirmed that job resources indeed mitigate the negative effect of job demands, with the exception of co-worker support. This finding could be explained by the fact that public drivers mainly work in isolation from other colleagues and they thus cannot count on their support and help during times of increased job demands. In other words, considering that drivers do not receive instrumental support from their co-workers, it cannot be expected that co-worker support could mitigate the negative effect of job demands on mental health in such circumstances.

\section{Theoretical contribution}

The main theoretical contribution of this study is that it enhances the understanding of the adverse effects of job demands and job resources in explaining employee mental health. More specifically, this study empirically proved the existence of an indirect positive effect of job resources, which act as relieving moderators in the negative relationship between job demands and mental health. In this regard, the present study adds to the literature related to job stress and burnout, and it is, in fact, the first study to empirically test the JD-R model in Croatia, using a sample of public-sector employees. While this model has so far been tested and confirmed in many countries (see e.g. Bakker \& Demerouti, 2016), the reported results from Croatia provide additional evidence for the reliability and validity of the JD-R model.

Furthermore, this study also contributes to the understanding of how specific stressors threaten employees' health and how specific resources protect employees from developing strain. However, the present study confirms the buffering effect of job resources on mental health, indicating that particular job resources such as co-worker support are experienced differently in the occupational group that includes high task interdependence and requires teamwork, compared to those jobs designed for providing standalone work efforts. 


\section{Practical implications}

The findings of the present study have important implications for organisational practices related to health protection of workers, in particular for those employed in the public transportation sector. The highly demanding work of public transportation drivers, both mentally and physically, is a work characteristic which should be taken into consideration in order to reduce and prevent negative outcomes that may arise. Here, this study provided evidence for a positive impact of received support from both co-workers and managers on the mental health of employees. Furthermore, this research also showed that particular job resources can mitigate negative effects of high job demands and they can thus be utilised to manage the mental health of employees. Moreover, organisational practices should be enriched by adding new job resources which can significantly buffer the negative effects of job demands to which drivers are exposed on a daily basis.

The results of this study can lay the foundation for redesign activities, conducting primary and secondary preventive measures as well as establishing better and healthier working conditions for employees in the public transportation sector.

\section{Study limitations and future research avenues}

The main limitation of the present study is the limited generalisability of its findings. Although the research sample can be regarded highly indicative for the population of Croatian public drivers, the study findings are not generalisable to other occupational groups. However, since being a public driver is a very stressful occupation in general, it can be assumed that the main findings of the research in the public sector are valid also in other countries, despite having somewhat different public transportation systems.

Another limitation relates to the limited range of work design characteristics which were tested, although there are certainly other characteristics which are distinctive for the work of public drivers. Future research may thus consider including additional work characteristics which are distinctive for public drivers. On the one hand, future research may focus on job demands, such as permanent contact with passengers, unpredictability in the working process, or task monotony. On the other hand, future studies may also encompass other job resources which could mitigate the negative influence of job demands, contribute to the motivational process and improve employee effectiveness (e.g. autonomy, quality of relationships with supervisor). 
DRUŠ. ISTRAŽ. ZAGREB GOD. 28 (2019), BR. 1 STR. 47-67

DEŽMAR KRAINZ, K ET AL.: DESIGNING...
Finally, a limitation of this study is the use of self-reported variables. In order to enhance the reliability and validity of measurements and findings, it would certainly be useful to combine self-reports and other ratings of job characteristics, on the one hand, and mental health, on the other. Moreover, future research may consider examining the possible direct influences of job demands on physical health. So far, studies have not focused on this relationship, but only on indirect effects mediated by mental health.

\section{REFERENCES}

Bakker, A. B., Demerouti, E., \& Schaufeli, W. B. (2003). Dual process at work in a call centre: An application of the job demands-resource model. European Journal of Work and Organizational Psychology, 12(4), 393-417. https://doi.org/10.1080/13594320344000165

Bakker, A. B., \& Demerouti, E. (2007). The job demands-resources model: State of the art. Journal of Managerial Psychology, 22(3), 309-328. https://doi.org/10.1108/02683940710733115

Bakker, A. B., Hakanen, J. J., Demerouti, E., \& Xanthopoulou, D. (2007). Job resources boost work engagement, particularly when job demands are high. Journal of Educational Psychology, 99(2), 274-284. https://doi.org/10.1037/0022-0663.99.2.274

Bakker, A. B., \& Demerouti, E. (2017). Job demands-resources theory: Taking stock and looking forward. Journal of Occupational Health Psychology, 22(3), 273-285. https://dx.doi.org/10.1037/ocp0000056

Chin, W. W., Marcolin, B. L., \& Newsted, P. N. (2003). A partial least squares latent variable modelling approach for measuring interaction effects: Results from a Monte Carlo simulation study and an electronic-mail emotion/adoption study. Information Systems Research, 14(2), 189-217. https://doi.org/10.1287/isre.14.2.189.16018

De Jonge, J., \& Dormann, C. (2006). Stressors, resources, and strain at work: A longitudinal test of the triple-match principle. Journal of Applied Psychology, 91(5), 1359-1374. https://doi.org/10.1037/0021-9010. 91.5.1359

Demerouti, E., Bakker, A. B., Nachreiner, F., \& Schaufeli, W. B. (2001). The job demands-resources model of burnout. Journal of Applied Psychology, 86(3), 499-512. https://doi.org/10.1037/0021-9010.86.3.499

Demerouti, E., \& Bakker, A. B. (2011). The job demands-resources model: Challenges from future research. Journal of Industrial Psychology, 37(2), 1-9. https://doi.org/10.4102/sajip.v37i2.974

Edwards, J. A., Webster, S., Van Laar, D., \& Simon, E. (2008). Psychometric analysis of the UK health and safety executive's management standards work-related stress indicator tool. Work $\mathcal{E}$ Stress: An International Journal of Work, Health E Organizations, 22(2), 96-107. https://doi. org/10.1080/02678370802166599

ENWHP - European Network for Workplace Health Promotion (2009). A guide to promoting mental health in the workplace: Employer's Resource. BKK Bundesverband, Essen. 
DRUŠ. ISTRAŽ. ZAGREB GOD. 28 (2019), BR. 1, STR. 47-67

DEŽMAR KRAINZ, K. ET AL.: DESIGNING...
Fassott, G., Henseler, J., \& Coelho, P. S. (2016). Testing moderating effects in PLS path models with composite variables. Industrial Management $\mathcal{E}$ Data Systems, 116(9), 1887-1900. https://doi.org/10.1108/IMDS06-2016-0248

Fornell, C., \& Larcker, D. F. (1981). Structural equation models with unobservable variables and measurement error: Algebra and statistics. Journal of Marketing Research, 18(3), 382-388. https://doi.org/10. $2307 / 3150980$

Grant, A. M., \& Parker, S. K. (2009). Redesigning work design theories: The rise of relational and proactive perspectives. The Academy of Management Annals, 3(1), 317-375. http://dx.doi.org/10.1080/19416520 903047327

Green, F. (2006). Demanding work: The paradox of job quality in the affluent economy. Princeton and Oxford, New Jersey: Princeton University Press.

Hackman, J. R., \& Oldhman, G. R. (1976). Motivation through the design of work: Test of a theory. Organizational Behaviour and Human Performance, 16(2), 250-279. https://doi.org/10.1016/0030-5073(76)90016-7

Hernaus, T. (2010). Integrating macro-organizational and micro-organizational variables through multilevel approach. (PhD dissertation). University of Zagreb, Faculty of Economics \& Business, Zagreb.

HSE - Health and Safety Executive (2004). Health and safety executive indicator tool. Available at http://www.hse.gov.uk/stress/assets/docs/ indicatortool.pdf

Henseler, J., \& Fassott, G. (2010). Testing moderating effects in PLS path models: An illustration of available procedures. In V. Esposito Vinzi, W. W. Chin, J. Henseler, \& H. Wang (Eds.), Handbook of partial least squares (pp. 713-735). Berlin, Heidelberg: Springer. https://doi. org/10.1007/978-3-540-32827-8_31

Hernaus, T., \& Mikulić, J. (2014). Work characteristics and work performance of knowledge workers. EuroMed Journal of Business, 9(3), 268-292. https://doi.org/10.1108/EMJB-11-2013-0054

Hernaus, T., \& Pološki Vokić, N. (2014). Work design for different generational cohorts: Determining common and idiosyncratic job characteristics. Journal of Organizational Change Management, 27(4), 615-641. https://doi.org/10.1108/JOCM-05-2014-0104

Johnson, J. V., \& Hall, E. M. (1988). Job strain, workplace social support, and cardiovascular disease: A cross-sectional study of a random sample of the Swedish working population. American Journal of Public Health, 78(10), 1336-1342. https://doi.org/10.2105/AJPH.78.10.1336

Karasek, R. A. (1979). Job demands, job decision latitude, and mental strain: Implications for job redesign. Administrative Science Quarterly, 24(2), 285-308. https://doi.org/10.2307/2392498

Karasek, R. A., \& Theorell, T. (1990). Healthy work: Stress, productivity and the reconstruction of working life. New York: Basic Books.

Kompier, M. A. J., \& Di Martino, V. (1995). Review of bus drivers' occupational stress and stress prevention. Stress Medicine, 11(1), 253-262. https://doi.org/10.1002/smi.2460110141 
DRUŠ. ISTRAŽ. ZAGREB GOD. 28 (2019), BR. 1 STR. 47-67

DEŽMAR KRAINZ, K. ET AL.: DESIGNING...
McHorney, C. A., Ware, J. E. Jr., Lu, J. F. R., \& Sherbourne, C. D. (1994). The MOS 36-Item Short-Form Health Survey (SF-36): III. Tests of data quality, scaling assumptions and reliability across diverse patient groups. Medical Care, 32(1), 40-66. https://doi.org/10.1097/00005650199401000-00004

Oldham, G. R., \& Fried, Y. (2016). Job design research and theory: Past, present and future. Organizational Behavior and Human Decision Processes, 136, 20-35. https://doi.org/10.1016/j.obhdp.2016.05.002

Panatik, S. A. B. (2010). Impact of work design on psychological work reactions and job performance among technical workers: A longitudinal study in Malaysia. (PhD dissertation). University of Waikato, Hamilton, New Zealand.

Parker, S. K. (2014). Beyond motivation: Job and work design for development, health, ambidexterity, and more. Annual Review of Psychology, 65(1), 661-691. https://doi.org/10.1146/annurev-psych-010213115208

Parker, S. K., \& Zhang, F. (2016). Designing work that works in the contemporary world: Future directions for job design research. In A. Shimazu, R. Bin Nordin, M. Dollard, \& J. Oakman (Eds.), Psychosocial factors at work in the Asia Pacific (pp. 135-150). Cham, Switzerland: Springer international Publishing. https://doi.org/10.1007/978-3-31944400-0_7

Ringle, C. M., Wende, S., \& Will, S. (2005). SmartPLS 2.0 (M3) Beta. Hamburg: University of Hamburg.

Schaufeli, W. B., \& Bakker, A. B. (2004). Job demands, job resources, and their relationship with burnout and engagement: A multi-sample study. Journal of Organizational Behavior, 25(3), 293-315. https://doi. org/10.1002/job.248

Silobrčić Radić, M., \& Jelavić, M. (2011). Veličina problema mentalnih/duševnih poremećaja u Hrvatskoj (The size of mental disorders problems in Croatia). In V. Kralj (Ed.), Mentalni poreméaji u Republici Hrvatskoj (Mental disorders in the Republic of Croatia) (pp. 2-26). Zagreb: Hrvatski zavod za javno zdravstvo.

Sikavica, P., \& Hernaus, T. (2011). Dizajniranje organizacije, strukture, procesi, poslovi (Designing organization, structures, processes, jobs). Zagreb: Novi informator.

Sinha, K. K., \& Van de Ven, A. H. (2005). Designing work within and between organizations. Organization Science, 16(4), 389-408. https://doi. org/10.1287/orsc.1050.0130

Stansfeld, S., \& Candy, B. (2006). Psychosocial work environment and mental health - A meta-analytic review. Scandinavian Journal of Work Environment and Health, 32(6), 443-426. https://doi.org/10.5271/sjweh.1050

Tims, M., Bakker, A. B., \& Derks, D. (2013). The impact of job crafting on job demands, job resources, and well-being. Journal of Occupational Health Psychology, 18(2), 230-240. https://doi.org/10.1037/a0032141

Useche, S. A., Alonso, F., Cendales, B. E., Autukevičiūte, R., \& Serge, A. (2017). Burnout, job strain and road accidents in the field of public transportation: The case of city bus drivers. Journal of Environmental and Occupational Science, 6(1), 1-7. https://doi.org/10.5455/jeos.201702 02074636 
DRUŠ. ISTRAŽ. ZAGREB GOD. 28 (2019), BR. 1, STR. 47-67

DEŽMAR KRAINZ, K. ET AL.: DESIGNING...
Van den Broeck, A., \& Parker, S. K. (2017). Job and work design. In O. Braddick (Ed.), Oxford research encyclopaedia of psychology (pp. 1-39). Oxford University Press, USA. https://doi.org/10.1093/acrefore/97801 90236557.013.15

Warr, P. (1994). A conceptual framework for the study of work and mental health. Work and Stress, 8(2), 84-97. https://doi.org/10.1080/ 02678379408259982

Ware, J. E., Snow, K. K., Kosinski, M., \& Gandek, B. (1993). SF- 36 Health Survey, Manual and interpretation guide. Boston, Massachusetts: The Health Institute.

Wynne, R., \& McAnney, D. (2004). Employment and disability: Back to work strategies, European Foundation for the improvement of living and working conditions. Available at http://digitalcommons.ilr.cornell.edu/ cgi/viewcontent.cgi? article $=1162 \&$ context $=$ gladnetcollect

World Health Organisation (2004). Promoting mental health: Concepts, emerging evidence practice (Summary report). WHO, Geneva. Available at http://www.who.int/mental_health/evidence/MH_Promotion_Book.pdf World Health Organisation (2005). Mental health policies and programmes in the workplace. WHO, Geneva. Available at http://www.who.int/ mental_health/policy/workplace_policy_programmes.pdf

World Health Organisation (2010). Health impact of psychosocial hazards at work: An overview. WHO, Geneva. Available at http://apps.who.int/ iris/bitstream/10665/44428/1/9789241500272_eng.pdf

Xanthopoulou, D., Bakker, A. B., Dollard, M. F., Demerouti, E., Schaufeli, W. B., Taris, T. W., \& Schreurs, P. J. G. (2007). When do job demands particularly predict burnout? The moderating role of job resources. Journal of Managerial Psychology, 22(8), 766-786. https://doi. org/10.1108/02683940710837714

\section{Dizajniranje posla za mentalno zdravlje: moderatorska uloga resursa posla}

Karmen DEŽMAR KRAINZ

Hrvatski zavod za zaštitu zdravlja i sigurnost na radu, Zagreb

Josip MIKULIĆ

Ekonomski fakultet, Zagreb

Helena KOREN

Hrvatski zavod za zaštitu zdravlja i sigurnost na radu, Zagreb

Ana ZAVALIĆ

Dom zdravlja Zagrebačke županije, Zaprešić

Cili je ovog rada istražiti odnos između karakteristika dizajna posla i ishoda zdravlja zaposlenika. Posebice su resursi posla (podrška menadžera, podrška kolega i informiranost o organizacijskim promjenama) ispitani kao moderator veze između zahtjeva posla (radno opterećenje i manjak kontrole) i mentalnoga zdravlja. Na temelju Modela zahtjeva i resursa posla, koristeći se tehnikom modeliranja strukturnih 
DRUŠ. ISTRAŽ. ZAGREB GOD. 28 (2019), BR. 1 STR. 47-67

DEŽMAR KRAINZ, K ET AL.: DESIGNING... jednadžbi metodom parcijalnih najmanjih kvadrata, autori pružaju empirijske dokaze na uzorku od 383 vozača u javnom prijevozu kako su zahtjevi posla negativno povezani s mentalnim zdravliem zaposlenika. Osim toga, resursi posla ublažavaju negativne učinke zahtjeva posla, osiguravajući tako alternativu za izbjegavanje procesa oštećenja zdravlja.

Ključne riječi: dizajn posla, Model zahtjeva i resursa posla, mentalno zdravlje, Hrvatska

\section{(c) $(1)(9$}

Međunarodna licenca / International License:

Imenovanje-Nekomercijalno/ Attribution-NonCommercial 